\title{
Variations in serum malondialdehyde levels in patients with leukemia
}

\author{
K. N. Pujari'1, S. P. Jadkar,", C. G. Patil ${ }^{3}$, Aruna Kulkarni', V. B. Tuljapurkar ${ }^{5}$ \\ ${ }^{1}$ Associate Professor, ${ }^{2}$ Reader, ${ }^{3}$ Asssitant Professor, ${ }^{4}$ Ex-Professor, ${ }^{5}$ Oncologist,,${ }^{1,2,4}$ Dept. of Biochemistry, ${ }^{3}$ Dept. of Preventive \\ and Social Medicine, ${ }^{5}$ Dept. of Medical Oncology, ${ }^{1,3,4}$ Government Medical College, Miraj, Maharashtra, ${ }^{2}$ PDP Dental College, \\ Kavlapur, Maharashtra, ${ }^{5}$ Shri Shiddhivinayak Ganapati Cancer Hospital, Miraj, Maharashtra, India
}

*Corresponding Author:

Email: pujari_karyappa@yhoo.in

Received: $20^{\text {th }}$ September, 2017

Accepted: $15^{\text {th }}$ February, 2018

\begin{abstract}
Leukemias are malignant neoplasms of hematopoietic stem cells characterized by diffuse infiltration of the blood and bone marrow by neoplastic cells. Leukemias are classified as acute and chronic according to clinical course and myeloid and lymphoid according to the cell predominantly involved in leukemic process. Free radicals are implicated in the pathogenesis of leukemia. Oxidative destruction of polyunsaturated fatty acid is called as lipid peroxidation. In this study, we determined serum malonyldialdehyde (MDA) level as a lipid peroxidation product in patients with leukemia. The mean serum MDA levels were significantly increased in leukemic patients $(\mathrm{p}<0.001)$ as compared to normal healthy controls. We observed significant difference in serum MDA levels with respect to sex only in patients with chronic myeloid leukemia. Whereas in age groups, we found significant trend in serum MDA levels in patients with CML, AML and ALL patients. There was no significant difference in serum MDA level in patients with CLL with respect to age. Our finding of the high levels of serum malondialdehyde in leukemic patients as compared to healthy control may be due to increased oxidative stress in patients with leukemia.
\end{abstract}

Keywords: Malondialdehyde, Leukemia, Oxidative stress.

\section{Introduction}

Leukemias are malignant neoplasms of hematopoietic stem cells characterized by diffuse infiltration of the blood and bone marrow by neoplastic cells. ${ }^{1,2}$ Leukemias are classified as acute or chronic based on clinical course and myeloid or lymphoid according to the cell predominantly involved in leukemic process. Free radicals are implicated in the pathogenesis of leukemia. Several mechanisms have been proposed that leads to oxidative stress in cancer., ${ }^{3,4}$

All cancers may begin with damage to the cells deoxyribonucleic acid (DNA). White blood cells which protect the body from infections are damaged in leukemia. DNA damage can occur in leukemia through chromosome translocations (shifting and rearrangement of chromosome segments) or mutations., Inherited, abnormal genes account for a small proportion of leukemic cases. ${ }^{7,8}$ However, in most cases, the DNA damage that eventually results in the onset of leukemia is a result of interactions between genes, age factor or due to variety of environmental and lifestyle factors such as nutrition and exposure to chemicals. ${ }^{5,6}$ This study was undertaken to estimate the oxidative stress marker malonyldialdehyde (MDA) in patients with different types of leukemia.

\section{Materials and Methods}

Present study was conducted in collaboration with Department of Biochemistry, Government Medical College and Medical Oncology Department of Shri
Siddhivinayak Ganpati Cancer Hospital, Miraj, Maharashtra (India).

Study protocol was approved by ethical committee of Government Medical College, Miraj, Maharashtra.

Sample Size: Total 172 subjects were included in this study. Out of which 132 subjects were leukemia patients and 40 were healthy controls.

Distribution of leukemic patients were made as follows:

1. Acute myeloid leukemia (AML): 35 patients

2. Acute lymphoblastic leukemia (ALL): 38 patients

3. Chronic myeloid leukemia (CML): 29 patients

4. Chronic lymphoblastic leukemia (CLL): 30 patients.

\section{Control}

Fourty normal healthy controls were enrolled from the OPD of Government Medical College Hospital and Shri Siddhivinayak Ganapati Cancer Hospital Miraj during the same period.

The subjects having history of alcoholism, smoking and other neoplastic, hematological conditions were excluded from the study.

Collection of blood samples: Informed consent was obtained from each subject. $2 \mathrm{ml}$ Blood samples was collected in plain bulb and clear serum was separated. Level of MDA in serum was measured by thiobarbituric acid reaction described by Kai Satoh (7) and the values were expressed in $\mathrm{nmol} / \mathrm{ml}$. Minitab version 13 was used for statistical evaluation of data. Student' $t$ ' test was applied to compare the difference between mean values. Annova test was used for the variations in serum MDA levels in leukemic patients with respect the various age groups. 


\section{Results}

Table 1: Serum MDA levels in patients and control.

\begin{tabular}{|l|c|c|}
\hline Subjects & n & MDA $(\mathbf{n m o l} / \mathbf{m l})$ \\
\hline Control & 40 & $5.8 \pm 0.32$ \\
\hline AML & 35 & $10.6 \pm 0.33^{* *}$ \\
\hline ALL & 38 & $10.41 \pm 0.20^{* *}$ \\
\hline CML & 29 & $9.15 \pm 0.55^{* *}$ \\
\hline CLL & 30 & $7.99 \pm 0.70^{* *}$ \\
\hline
\end{tabular}

The values are Mean \pm SD

$* *$ values shows $\mathrm{p}<0.001$ (highly significant)

Table 1 shows the levels of serum MDA in leukemia and healthy control. We found significantly increased serum MDA levels in all leukemic patients $(\mathrm{p}<0.001)$.

Table 2: Serum LPO (nmol/ml) levels in males and females with leukemias

*values shows $\mathrm{p}<0.05$ (highly significant), NS=Non-significant

\begin{tabular}{|l|l|c|c|c|c|}
\hline & & AML & ALL & CML & CLL \\
\hline \multirow{3}{*}{ Males } & $\mathrm{N}$ & 18 & 28 & 20 & 14 \\
\cline { 2 - 6 } & Mean & 10.64 & 10.43 & 9.29 & 8.18 \\
\cline { 2 - 6 } & SD & 0.34 & 0.13 & 0.43 & 0.98 \\
\hline \multirow{3}{*}{ Females } & $\mathrm{N}$ & 17 & 10 & 9 & 16 \\
\cline { 2 - 6 } & Mean & 10.59 & 10.37 & 8.82 & 7.82 \\
\cline { 2 - 6 } & SD & 0.32 & 0.34 & 0.67 & 0.20 \\
\hline \multicolumn{2}{|l|}{ TEST STATISTICS } & 0.71 & 0.79 & 2.27 & 1.43 \\
\multicolumn{2}{l|}{ Student - t test } & $0.48 \mathrm{NS}$ & $0.44 \mathrm{NS}$ & $0.031^{*}$ & $0.16 \mathrm{NS}$ \\
\hline
\end{tabular}

Table 2 compares serum MDA levels in male and female in different types of leukemia. A significant difference in serum MDA value with respect to sex was observed only in CML patients.

Table 3: Variation in the serum MDA $(\mathrm{nmol} / \mathrm{ml})$ levels in leukemic patients with respect the different age groups

\begin{tabular}{|c|c|c|c|c|c|c|c|c|c|c|c|c|}
\hline & & AML & & & ALL & & & CML & & & CLL & \\
\hline Age & $\mathrm{N}$ & Mean & $\mathrm{Sd}$ & $\mathrm{N}$ & Mean & $\mathrm{Sd}$ & $\mathrm{N}$ & Mean & $\mathrm{Sd}$ & $\mathrm{N}$ & Mean & $\mathrm{Sd}$ \\
\hline$<10$ & 4 & 10.20 & 0.00 & 16 & 10.44 & 0.11 & - & - & - & - & - & - \\
\hline $11-20$ & 9 & 10.52 & 0.34 & 10 & 10.35 & 0.14 & 1 & 8.0000 & - & - & - & - \\
\hline $21-30$ & 5 & 10.50 & 0.37 & 6 & 10.25 & 0.08 & 6 & 8.6000 & 0.30984 & 1 & 7.4000 & - \\
\hline $31-40$ & 4 & 10.70 & 0.38 & 1 & 10.50 & - & 4 & 8.9250 & 0.61847 & 3 & 7.5000 & 0.10000 \\
\hline $41-50$ & 4 & 10.85 & 0.10 & 1 & 10.30 & - & 4 & 9.1750 & 0.53151 & 4 & 7.7250 & 0.27538 \\
\hline$>51$ & 9 & 10.76 & 0.25 & 4 & 10.73 & 0.40311 & 14 & 9.5143 & 0.24763 & 22 & 8.1273 & 0.75981 \\
\hline Total & 35 & 10.60 & 0.33 & 38 & 10.41 & 0.20158 & 29 & 9.1448 & 0.55006 & 30 & 7.9867 & 0.69814 \\
\hline $\begin{array}{l}\text { Test } \\
\text { statistics }\end{array}$ & & $\begin{array}{c}2.94 \\
0.029 *\end{array}$ & & & $\begin{array}{c}4.47 \\
0.003 *\end{array}$ & & & $\begin{array}{c}9.53 \\
0.001 * *\end{array}$ & & & $\begin{array}{c}1.24 \\
0.317 \mathrm{NS}\end{array}$ & \\
\hline
\end{tabular}

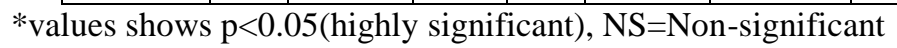

Table 3 shows the variations in serum MDA levels in leukemic patients with respect their age groups. Significant positive trend in serum MDA levels with respect to age was observed in AML $(\mathrm{P}<0.029)$ and ALL $(\mathrm{P}<0.003)$ patients. Whereas, highly significant positive trend in serum MDA level was observed in CML patients $(\mathrm{P}<0.001)$ with different age. There was no such significant trend in CLL patients with different age.

\section{Discussion}

Lipid peroxidation plays a significant role in the pathogenesis of many conditions including carcinogenesis (10). Free radicals are also able to mediate the activation of carcinogens to electrophilic, DNA damaging moieties and play an indirect role in carcinogenesis as mediators of hydroperoxide dependent oxidation of carcinogens. ${ }^{11}$
We found significantly increased serum MDA level in leukemic patients as compared to control (Table 1). Some previous studies shows increased MDA levels in different types of leukemia. ${ }^{10,12,13}$ Oxidative stress occurring in patients with leukemia may be due to the elevated number of mature and immature myeloid or lymphoid series cells. ${ }^{1,2,10}$ This can also due to increased formation or reduced clearance of free radicals by the cellular antioxidant system. ${ }^{12,13}$

Several mechanisms leading to oxidative stress have been proposed in cancer patients. Altered energy metabolism may be attributable to symptoms such as anorexia/ cachexia, nausea and vomiting. These prevent normal nutrition and there by a normal supply of nutrients such as glucose, protein and vitamins. Overall effect of above mentioned conditions accumulates reactive oxygen species (ROS). ${ }^{14} \mathrm{CLL}$ is a non specific chronic disease which in turn may increase ROS production. Another mechanism may be the result of 
the use of antineoplastic drugs, particularly alkylating agents and Cisplastin. These are able to produce an excess of ROS and therefore lead to oxidative stress. ${ }^{15}$

The significant difference in serum MDA levels with respect to sex are observed only in CML patients (Table 2). AML, ALL and CLL have exhibited increased MDA levels, though sex difference was not apparent. This may indicate failure of antioxidant system to neutralize the extensive oxidative damage resulting in leukemia which progresses aggressively in short time. ${ }^{16}$

Table 3 shows the variations of serum MDA levels in the leukemic patients with different age groups. We found significant positive trend in MDA levels with respect to age in AML, ALL and CML patients. This may be due to reduced antioxidant defense system with increase in age. ${ }^{13}$ Absorption or uptake and capacity body to absorb natural antioxidants may be reduced with increase in age. ${ }^{17}$ According to study of Kesavulu et $\mathrm{al}^{18}$ excessive production of free radicals in the organism and the imbalance between the concentration of these free radicals and the antioxidant defenses was related to the processes like aging and development of several diseases like cancer.

\section{Conclusion}

Our study suggests the high levels of serum malondialdehyde in leukemic patients as compared to healthy control may due to increased oxidative stress in patients.

\section{References}

1. Frank Firkin, Colin Chesterman, David penington and Bryan Rush. The leuckemias: in de Gruch's Clincial Haematology in Medical practice. Blackwell science Ltd. 1996, page No. 236-77.

2. K. N. Pujari, Aruna Kulkarni, V. B. Tuljapurkar, R. M. Joshi and Asma Mujawar. Free radical and antioxidant enzymes in acute leukemia. The antiseptic April 2008, 105(4):168-9.

3. K. N. Pujari, Aruna Kulkarni, V. B. Tuljapurkar, M. K. Surwanshi, R. M. Joshi and Asma Mujawar. Lipid peroxidation and antioxidant enzymes in chronic leukemia. Spectrum: Journal of Medical Research. JanDec 2007:4(1 \& 2):60-3.

4. K. N. Pujari, S. P. Jadkar, Aruna Kulkarni, V. B. Tuljapurkar, R. M. Joshi and Asma Mujawar Biochemical parameters in leukemia. The antiseptic April 2011, 108(8):174-7.

5. Greaves MF. Biological models for leukaemia and lymphoma. IARC Sci Publ. 2004 ; (157):351-72.

6. Irons RD and Stillman WS. The process of leukemogenesis. Environ Health Perspect. 1996 Dec; 104 Suppl 6:1239-46.

7. Alter BP. Cancer in Fanconi anemia, 1927-2001. Cancer 2003 Jan 15; 97(2):425-40.

8. Bischof O, Kim SH. et al. Regulation and localization of the Bloom syndrome protein in response to DNA damage. J Cell Biol 2001 Apr 16;153(2):367-80.
9. Satoh K. Serum lipid peroxide in cerebrovascular disorders determined by a new colorimetric method. Clinica. Chimica Acta 1978;90:37-43.

10. Leukemia Atheer A. Mehde and Ammar M.Yousif. Estimation of Malondialdehyde, Total Antioxidant Capacity and Some Biochemical Parameters in CSF and Sera of Patients with Acute Lymphoblastic. Australian Journal of Basic and Applied Sciences Sept 2014;8(15):329-33.

11. Marnett L. Peroxyl free radicals: potential mediators of tumor initiation and promotion. Carcinogenesis 1987;8:1365-73

12. Maria Juracy Petrola, Alana Joselina Montenegro de Castro, Maria Helena da Silva Pitombeira, Maritza Cavalcante Barbosa, Acy Telles de Souza Quixada, Fernando Barroso Duarte and Romelia Pinheiro Goncalves. Serum concentrations of nitrite and malondialdehyde as markers of oxidative stress in chronic myeloid leukemia patients treated with tyrosine kinase inhibitors. Rev Bras Hematol Hemoter. 2012;34(5):352-5.

13. Ullagaddi Rajeshwari, Iyer Shobha, Rao Raghunatha and Bondada Andallu. Oxidative Stress and Antioxidant Status in Acute and Chronic Myeloid Leukemia Patients. Open Journal of Blood Diseases, 2013,3,17-22

14. Oltra AM, Carbonell F, Tormos C, Iradi A and Saez GT. Antioxidant enzyme activities and the production of MDA and 8-oxi-dG in chronic lymphocytic leukemia. Free Radic Biol Med 2001 Jun 1;30(11):1286-92.

15. Weijl NI, Cleton FJ and Osanto S. Free radicals and antioxidants in chemotherapy- induced toxicity. Cancer Treat. Rev. 1997;23:209-40.

16. K. N. Pujari, S.P. Jadkar, Aruna Kulkarni, C.G. Patil, V.B. Tuljapurkar. Superoxide dismutase levels in leukemias. International Journal of Basic Medical Sciences May 2011, 2(2):96-100.

17. K. N. Pujari, S. P. Jadkar, S. N. Mashal, G. J. Belwalkar, Aruna kulkarni, C. G. Patil, and V. B. Tuljapurkar. Variations in Vitamin C Levels in Leukemias. Biomedical Research 2012;23(2):307-311.

18. Kesavulu MM, Rao BK, Giri R, Vijaya J, Subramanyam G. Alterations of antioxidant enzymes and oxidative stress markers in aging. Kasapoglu M, Ozben T, Apparao C. Expgerontol 2001;36:209. 